\title{
Resting metabolic rate and body temperature in the aquatic tenrec Limnogale mergulus (Insectivora: Tenrecidae)
}

\author{
Peter J. STEPHENSON
}

\begin{abstract}
Stephenson P. J. 1994. Resting metabolic rate and body temperature in the aquatic tenrec Limnogale mergulus (Insectivora: Tenrecidae). Acta theriol. 39: 89-92.

This paper presents the first recorded measures of resting metabolic rate and body temperature in the tenrec Limnogale mergulus Major, 1896. The preliminary results suggest that, although this is the only aquatic species within the family Tenrecidae, it does not maintain either resting metabolic rate or body temperature at an elevated level. Further studies of this rare, aquatic insectivore are recommended.

Department of Zoology, University of Aberdeen, Aberdeen AB9 2TN, United Kingdom

Key words: aquatic tenrec, Limnogale mergulus, mammalian energetics, Tenrecidae
\end{abstract}

\section{Introduction}

The family Tenrecidae (Insectivora) represents an early lineage of eutherian mammals endemic to the Indian Ocean island of Madagascar (Eisenberg and Gould 1970). Early studies on species in the subfamily Tenrecinae suggested that tenrecs were characterised by low metabolic rates and low and variable body temperatures (e.g. Herter 1962, Hildwein 1970, Eisenberg and Gould 1970). However, Microgale species in the subfamily Oryzorictinae have resting metabolic rate close to the level expected for mammals of their body mass (Stephenson 1991, Stephenson and Racey 1993b).

The aquatic tenrec Limnogale mergulus Major, 1896 is the largest species within the Oryzorictinae and the only tenrec adapted to an aquatic environment (Malzy 1965, Gould and Eisenberg 1966). Vertebrates from aquatic or marine environments tend to have elevated levels of metabolism (e.g. Scholander et al. 1950, McNab 1978, 1986, Bennett and Harvey 1987) but no physiological data are available for $L$. mergulus. This paper provides preliminary data on resting metabolic rate and body temperature in the first aquatic tenrec ever held in captivity.

\section{Materials and methods}

In July 1989, a male L. mergulus was captured in a river at Ranomafana forest, south-east Madagascar (E. Gould, pers. comm.), and transported to the Parc Botanique et Zoologique de Tsimbazaza, Antananarivo. There it was maintained in captivity for six weeks. The animal was 
housed in a wooden crate with sawdust and dry leaves as bedding. A plastic tube facilitated access to a water-filled aquarium in which a rock was positioned as a feeding platform. A diet of freshly caught fish, frogs and crabs was provided daily.

Oxygen consumption was measured in an open circuit respirometry system using an Applied Electrochemistry S3A-1 oxygen analyser (Ametek, PA, USA) as described elsewhere (Stephenson and Racey 1993a). The animal was placed in a perspex respirometry chamber of $2.5 \mathrm{l}$ and submerged in a circulating water bath for at least $2 \mathrm{~h}$. Oxygen consumption was measured whilst the water bath maintained an ambient temperature $\left(\mathrm{T}_{\mathrm{a}}\right)$ of $29-30^{\circ} \mathrm{C}$, which is within the thermoneutral zone defined for other species of Oryzorictinae (Stephenson 1991). Resting metabolic rate (RMR) was measured whilst the animal was postabsorptive and at rest during its daily period of inactivity $(06.00-18.00 \mathrm{~h})$. A measure of RMR was only taken if the animal had been inactive in the respirometer for at least 30 minutes and oxygen consumption was constant. Although four measures were made, the animal failed to settle on one occasion.

Immediately following all measures of oxygen consumption, the animal was removed from the respirometry chamber and, prior to being weighed, cloacal body temperature $\left(\mathrm{T}_{\mathrm{b}}\right)$ was measured to an accuracy of $0.1^{\circ} \mathrm{C}$.

\section{Results and discussion}

Mean body mass of the study animal (Table 1) was within the range of $62-90 \mathrm{~g}$ recorded for other adult wild-caught males (Malzy 1965). During respirometry, cloacal body temperature was maintained relatively constant around $32.5^{\circ} \mathrm{C}\left(3^{\circ} \mathrm{C}\right.$ above mean $\mathrm{T}_{\mathrm{a}}$ ). Under the same ambient conditions, mean $\mathrm{T}_{\mathrm{b}}$ in five other species of Oryzorictinae ranges from 30.8-33.9 ${ }^{\circ} \mathrm{C}$ (Stephenson and Racey 1993a, b).

Mean RMR in L. mergulus was $72.3 \mathrm{mlO}_{2} \times \mathrm{h}^{-1}$. Although this value was obtained from three measures on a single individual, there is no reason to believe this is not a valid approximation of RMR in this species. In four other species of oryzorictine tenrec, the first three measures on a solitary male gave an approximation that ranged from $95 \%$ to $115 \%$ of the value for RMR established from a number of individuals (Table 2). Assuming the same pattern in L. mergulus, RMR for this species would be expected to be between 62.7 and $76.3 \mathrm{mlO}_{2} \times \mathrm{h}^{-1}$. This represents 79-96\% of the value expected for a eutherian mammal of its body mass (McNab 1988). In comparison, other oryzorictine tenrecs have RMR ranging from $55 \%$ (Geogale aurita) to $144 \%$ (Microgale cowani) of the expected value (Stephenson and Racey 1993a, b). Therefore, from these preliminary results, L. mergulus does not appear to maintain $\mathrm{T}_{\mathrm{b}}$ or RMR at a higher level than other oryzorictine tenrec species. This contrasts with the trend identified in other aquatic vertebrates which normally maintain RMR and $\mathrm{T}_{\mathrm{b}}$ at levels higher than expected from body mass

Table 1. Mean body mass, ambient temperature $\left(\mathrm{T}_{\mathrm{a}}\right)$, body temperature $\left(\mathrm{T}_{\mathrm{b}}\right)$ and resting metabolic rate (RMR) during three measures on a captive male L. mergulus. Mean values are presented with standard error in parentheses.

\begin{tabular}{lccc}
\hline Body mass $(\mathrm{g})$ & $\mathrm{T}_{\mathrm{a}}\left({ }^{\circ} \mathrm{C}\right)$ & $\mathrm{T}_{\mathrm{b}}\left({ }^{\circ} \mathrm{C}\right)$ & $\mathrm{RMR}_{\left(\mathrm{mlO}_{2} \times \mathrm{h}^{-1}\right)}$ \\
\hline $77.7(1.5)$ & $29.5(0.06)$ & $32.5(0.24)$ & $72.3(14.4)$ \\
\hline
\end{tabular}


Table 2. Mean ( \pm one SE) of first three measures of RMR in individual male tenrecs in relation to established RMR of species. Data from Stephenson and Racey (1993a, b) and P. J. Stephenson (unpubl.).

\begin{tabular}{lccc}
\hline Species & $\begin{array}{c}\text { Species } \mathrm{RMR} \\
\left(\mathrm{mlO}_{2} \times \mathrm{h}^{-1}\right)\end{array}$ & $\begin{array}{c}\text { Mean } \mathrm{RMR} \text { of one male } \\
(n=3)\left(\mathrm{mlO}_{2} \times \mathrm{h}^{-1}\right)\end{array}$ & $\begin{array}{c}\text { Male RMR }(\% \text { of } \\
\text { species RMR })\end{array}$ \\
\hline Geogale aurita & 7.7 & $7.3 \pm 0.3$ & 95 \\
Microgale cowani & 27.0 & $27.2 \pm 4.2$ & 101 \\
Microgale dobsoni & 41.7 & $46.7 \pm 10.3$ & 112 \\
Microgale talazaci & 43.5 & $50.2 \pm 10.1$ & 115 \\
\hline
\end{tabular}

(e.g. Scholander et al. 1950, McNab 1978, 1986, Bennett and Harvey 1987), possibly to compensate for the high rates of heat loss experienced in water (McNab 1980). However, when compared with other marsupials, the water opossum Chironectes minimus, also shows no elevated level of metabolic rate (Thompson 1988). Therefore, the association between elevated RMR and aquatic habits may not be uniform throughout Mammalia. Furthermore, most aquatic mammals are carnivores and this diet may be the primary cause of an elevated metabolic rate (McNab 1980). In L. mergulus, it is possible that heat production may be increased periodically by bouts of activity or by energy generated from food digestion (SDA), as in the sea otter Enhydra lutris (Costa and Kooyman 1982, 1984). Muscular activity during swimming or SDA may therefore be sufficient to maintain an adequately high $\mathrm{T}_{\mathrm{b}}$ without the need for an elevated RMR.

In the temperate Soricidae, water shrews are amongst the largest species (Genoud 1988). This may provide them with a greater thermal inertia to reduce the loss of body heat during time submerged underwater. L. mergulus is the largest species of oryzorictine tenrec, with a mean body mass almost twice that of the next largest species, M. talazaci (Stephenson 1991). Therefore, a reduction in thermal inertia through increased body size, rather than elevated metabolic rate, may be the main adaptation of $L$. mergulus to an aquatic mode of life. However, further studies are required on a larger sample size to determine the energetic strategies of this rare insectivore.

Acknowledgements: I would like to thank Dr E. Gould (Smithsonian Institution, Washington DC) for supplying the study animal, and Dr V. Randrianasolo and staff at Parc Tsimbazaza for their assistance with captive maintenance. I am also grateful for the help and collaboration of the Département des Eaux et Forêts, the Ministère de l'Enseignement Supérieur and WWF-Aires Protégées. Prof P. A. Racey (Aberdeen University) and Dr M.E. Nicoll (WWF) provided invaluable advice and support throughout my work in Madagascar, which was funded by a Natural Environment Research Council studentship.

\section{References}

Bennett P. M. and Harvey P. H. 1987. Active and resting metabolism in birds: allometry, phylogeny and ecology. J. Zool., Lond. 213: 327-363. 
Costa D. P. and Kooyman G. L. 1982. Oxygen consumption, thermoregulation, and the effect of fur oiling and washing on the sea otter Enhydra lutris. Can. J. Zool. 60: 2761-2767.

Costa D. P. and Kooyman G. L. 1984. Contribution of specific dynamic action to heat balance and thermoregulation in the sea otter Enhydra lutris. Physiol. Zool. 57: 199-203.

Eisenberg J. F. and Gould E.. 1970. The tenrecs: a study in mammalian behavior and evolution. Smithson. Contrib. Zool. 27: 1-127.

Genoud M. 1988. Energetic strategies of shrews: ecological constraints and evolutionary implications. Mammal Rev. 18: 173-193.

Gould E. and Eisenberg J. F. 1966. Notes on the biology of the Tenrecidae. J. Mammal. 47: 660-686.

Herter K. 1962. Untersuchungen an lebenden Borstenigeln (Tenrecinae), 1: Über Temperaturregulierung und Aktivitätsrhythmik bei dem Igeltanrek Echinops telfairi Martin. Zool. Beitr. 7: 239-292.

Hildwein G. 1970. Capacités thermorégulatrices d'un mammifere insectivore primitif, le Tenrec; leurs variations saisonnières. Arch. Sci. Physiol. 25: 55-71.

Malzy P. 1965. Un mammifere aquatique de Madagascar: le Limnogale. Mammalia 29: 399-411.

McNab B. K. 1978. The comparative energetics of neotropical marsupials. J. Comp. Physiol. 125: $115-128$.

McNab B. K. 1980. Food habits, energetics, and the population biology of mammals. Am. Nat. 116: 106-124.

McNab B. K. 1986. The influence of food habits on the energetics of eutherian mammals. Ecol. Monogr. 56: 1-19.

McNab B. K. 1988. Complications inherent in scaling the basal rate of metabolism in mammals. Quart. Rev. Biol. 63: 25-54.

Scholander P. F., Hock R., Walters V. and Irving L. 1950. Adaptation to cold in arctic and tropical mammals and birds in relation to body temperature, insulation, and basal metabolic rate. Biol. Bull. 99: 259-271.

Stephenson P. J. 1991. Reproductive energetics of the Tenrecidae (Mammalia: Insectivora). Ph. D. thesis, University of Aberdeen, UK: 1-257.

Stephenson P. J. and Racey P. A. 1993a. Reproductive energetics of the Tenrecidae (Mammalia: Insectivora), I: the large-eared tenrec, Geogale aurita. Physiol. Zool. 66: 643-663.

Stephenson P. J. and Racey P. A. 1993b. Reproductive energetics of the Tenrecidae (Mammalia: Insectivora), II: the shrew-tenrecs, Microgale spp. Physiol. Zool. 66: 664-685.

Thompson S. D. 1988. Thermoregulation in the water opossum (Chironectes minimus): an exception that 'proves' a rule. Physiol. Zool. 61: 450-460.

Received 23 August 1993, accepted 22 December 1993. 